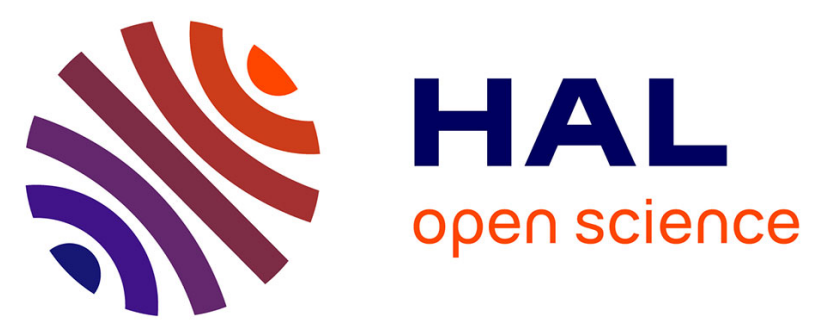

\title{
Aggregation-based in silico study for better understanding of related membrane interfering analogous of Amphotericin B
}

\author{
Sardari Soroush, Saied Mostaan, Azerang Parisa
}

\section{To cite this version:}

Sardari Soroush, Saied Mostaan, Azerang Parisa. Aggregation-based in silico study for better understanding of related membrane interfering analogous of Amphotericin B. Proceedings of the III International Conference on Environmental, Industrial and Applied Microbiology (BioMicroWorld2009), Dec 2010, Lisbon, Portugal. pp.668-671, 10.1000/ISBN978-981-4322-11-9 . pasteur-00746845

\section{HAL Id: pasteur-00746845 \\ https://hal-riip.archives-ouvertes.fr/pasteur-00746845}

Submitted on 29 Oct 2012

HAL is a multi-disciplinary open access archive for the deposit and dissemination of scientific research documents, whether they are published or not. The documents may come from teaching and research institutions in France or abroad, or from public or private research centers.
L'archive ouverte pluridisciplinaire HAL, est destinée au dépôt et à la diffusion de documents scientifiques de niveau recherche, publiés ou non, émanant des établissements d'enseignement et de recherche français ou étrangers, des laboratoires publics ou privés. 


\section{Microorganisms In Industry And Environment}

From Scientific and Industrial Research to Consumer Products

Proceedings of the III International Conference on Environmental, Industrial and Applied Microbiology (BioMicroWorld2009)

Lisbon, Portugal, 2 - 4 December 2009

S. Sardari, S. Mostaan, and P. Azerang (2010) Aggregation-based in silico study for better understanding of related membrane interfering analogous of Amphotericin B. Microorganisms In Industry And Environment: pp. 668-671.

Methods

\section{Aggregation-based in silico study for better understanding of related membrane interfering analogous of Amphotericin B}

S. Sardari

- Corresponding author: fax: (98-21) 6648 0780, phone: (98-21) 66953311.

Drug Design and Bioinformatics Unit, Medical Biotechnology Department, Biotechnology Research Center, Pasteur Institute of Iran, \#69 Pasteur Ave. Tehran, Iran 13164, Iran

S. Mostaan

Drug Design and Bioinformatics Unit, Medical Biotechnology Department, Biotechnology Research Center, Pasteur Institute of Iran, \#69 Pasteur Ave. Tehran, Iran 13164, Iran

P. Azerang

Drug Design and Bioinformatics Unit, Medical Biotechnology Department, Biotechnology Research Center, Pasteur Institute of Iran, \#69 Pasteur Ave., Tehran, Iran 13164, Iran

Amphotericin B (AmB) is a choice antibiotic against fungal infections. Since AmB has many side effects, it is desired to come up with new molecules with similar activity and less toxicity. In this work, attempt has been made to design a series of molecules by chem/bioinformatics. The structure of AmB was divided into two fragments and the best modified molecules were chosen, according to binding energy obtained through in silico dock experiments. A similarity search was performed on the molecules, and the available similar compounds resulted to a set of structurally matched compounds with $70 \%$ and above for similarity value. Several molecules from the library were selected and evaluated for in vitro antifungal assay. The result of the evaluations was finding compounds, which their antifungal effect had not been reported before or proposed new mechanism of action possibly involve in binding to membrane components such as ergosterol.

Keywords: Amphotericin B; interaction energy; ergosterol; cholesterol; similarity search 